\title{
Dissolved and particulate organic matter as possible food sources for eel leptocephali
}

\author{
Tsuguo Otake ${ }^{1}$, Kinya Nogami ${ }^{2}$, Keigo Maruyama ${ }^{2}$ \\ ${ }^{1}$ Ocean Research Institute, University of Tokyo, Tokyo 164, Japan \\ ${ }^{2}$ Japan Sea Farming Association, Tamano Station, Tamano, Okayama 706, Japan
}

\begin{abstract}
The gut contents and ultrastructure of midgut mucosal cells were examined in the leptocephali of Conger myriaster. Detrital aggregates less than $20 \mu \mathrm{m}$ in diameter and fecal pellets of zooplankton, which were collectively called 'particulate organic matter' (POM), were found in the gut of $78 \%$ of leptocephali examined. These particulate materials were also present in over $90 \%$ of the gut of C. japonicus and Muraenosox cinereus leptocephali which were collected in the same waters. The POM is thought to be a major food item of leptocephali. Gut pigment contents were low in C. myriaster, indicating no feeding on phytoplankton. Active seawater ingestion was ultrastructurally indicated in midgut mucosal epithelium, which suggested that dissolved organic matter (DOM) was another possible nutritive source. The stable nitrogen isotopic composition of C. myriaster leptocephali, a reliable indicator of trophic position in food webs, was at the lowest level, equal to that of POM. This result strongly supports our suggestion that POM and DOM are food sources for eel leptocephali.
\end{abstract}

\section{INTRODUCTION}

Little is known of the early life history of eel leptocephali. In particular their nutrition is enigmatic, since no food has ever been found in their guts (Moser 1981). Their poorly differentiated gut (Hulet 1978), equilibrium of body ionic composition with seawater (Hulet et al. 1972), and high level of essential amino acids (Pfeiler 1986) provoked the hypothesis that nutrition is furnished by epidermal uptake of dissolved organic matter (DOM) (Hulet 1978, Pfeiler 1986).

In the Seto Inland Sea, Japan, the leptocephalus larvae of Conger myriaster (Brevoort) commonly appear between March and May. Large numbers of the larvae are often caught with bag nets and bull trawls for sand eel or sardine fishing conducted in the water during those months. Here, we present data on their gut contents, gut pigment content, and ultrastructure of midgut mucosal epithelium, suggesting that eel leptocephali obtain nutrition from particulate organic matter (POM) and DOM.

The isotopic distribution in animals has been found to be closely related to dietary isotopic composition. The nitrogen heavy isotope $\left({ }^{15} \mathrm{~N}\right)$ is known to be regularly enriched by 3 to $4 \%$ per trophic level (DeNiro \& Epstein 1981, Schoeninger \& DeNiro 1984, Minagawa
\& Wada 1984, Wada et al. 1987, Fry 1988). Therefore, we examined nitrogen isotopic composition to estimate the trophic position of leptocephali in the food web and to aid in detecting the food source

\section{MATERIALS AND METHODS}

Gut contents. A total of 423 pre-metamorphic leptocephali of Conger myriaster (78.1 to $128.7 \mathrm{~mm}$ total length) were used for examination of gut contents. The leptocephali were collected by bag nets and bull trawls for sand eel or sardine fishing conducted in an area 25 to $50 \mathrm{~m}$ deep in Harimanada, the Seto Inland Sea, Japan, in March-April 1989 and 1990. Each net was operated at depths from $20 \mathrm{~m}$ to the surface during daylight hours $(07: 00$ to $14: 00 \mathrm{~h})$. A total of 86 pre-metamorphic leptocephali of $C$. japonicus ( 76.7 to $117.3 \mathrm{~mm}$ total length), collected concurrently with C. myriaster, and 104 of Muraenosox cinereus ( 35.0 to $90.2 \mathrm{~mm}$ total length), collected in the same area from August to October 1989, were also examined for gut contents. Surface water temperature and salinity of the sampling area were 10.1 to $13.0^{\circ} \mathrm{C}$ and 31.9 to $32.8 \%$ during March-April in 1989 and 1990 , and 23.1 to $26.4^{\circ} \mathrm{C}$ and 30.6 to $31.4 \%$ during August-October in 1990 . Specimens were preserved in 
$10 \%$ neutralized formalin or $2 \%$ paraformaldehyde $2 \%$ glutaraldehyde mixture in $0.1 \mathrm{M}$ cacodylate buffer $(\mathrm{pH}$ 7.4). After measurements and myomere counts following the methods described by Jespersen (1942) and Castle (1963), gut contents were examined under a binocular dissecting microscope. Some identifiable gut contents were examined further with scanning and transmission electron microscopes.

For scanning electron microscopy (SEM) the gut was removed and cut into several pieces, which were postfixed in $2 \% \mathrm{OsO}_{4}$ for $2 \mathrm{~h}$, dehydrated through a graded ethanol series, and dried in a Hitachi HCP-2 critical point dryer. The dried tissues were mounted on a brass disc and cut into halves using a needle and razor to expose the inner surface. They were subsequently sputter-coated with gold in a Jeol JFC-1100 ion-sputterer and observed under an Akashi-a25 SEM.

The procedure for transmission electron microscopy (IEM) was the same as that for ulirastructural examination of midgut epithelium, described below.

Gut pigment contents: A total of 32 Conger myriaster leptocephali collected concurrently with the specimens fur gut content analysis were uscd for examination of gut pigment content. After the total length was measured, each gut was removed and dipped in dimethylformamid to extract chlorophyll a (chl a) and phaeopigment. Gut pigment content was then measured with a Turner model 111 fluorescent photometer after Strickland \& Parsons (1972). The pigment contents were expressed as chl a + phaeopigment, where phaeopigment was converted to chl a equivalent weight.

Ultrastructure of midgut epithelium. For TEM the midgut of several Conger myriaster leptocephali were fixed in cold $2 \%$ paraformaldehyde $/ 2 \%$ glutaraldehyde mixture in $0.1 \mathrm{M}$ cacodylate buffer ( $\mathrm{pH} 7.4$ ) for several days. After post-fixation and dehydration in the same manner as for SEM, the tissues were embedded in Epon 812 resin. Ultra-thin sections were cut using an LKB-Ultrotome(V), double stained with uranyl acetate and lead citrate, and examined with a Jeol JEM-100CX TEM. Some thicker sections were stained with toluidine blue and observed under a light microscope.
Stable nitrogen isotopic composition. Stable nitrogen isotopic compositions were measured for Conger myriaster leptocephali and other fishes (sand eel Ammodytes personatus, gizzard shad Clupanodon punctatus, and cardinal fish Apogon lineatus), and invertebrates such as squid (Loligo sp.) and jellyfish, which were taken concurrently in the bag net. In order to avoid contamination from diet isotopic composition, trunk muscle was used for analysis in fishes, and whole body without gut was used in leptocephali and other fish larvae. Mantle and umbrella were examined for squid and jellyfish, respectively. POM and plankton sample were also examined. POM was collected by filtering 15 to $20 \mathrm{l}$ of seawater (1989 sample: $20 \mathrm{~m}$ depth; 1990 samples: 0, 15 , and $20 \mathrm{~m}$ ) using a precombusted $\left(400^{\circ} \mathrm{C}, 5 \mathrm{~h}\right)$ silica filter (pore size $0.22 \mu \mathrm{m}$ ). A plankton sample comprising copepods such as Acartia omorii, Calanus sinicus and Centropages abdominalis, as well as Oikopleura spp. and diatoms, was collected by vertical haul from the bottom (ca. $45 \mathrm{~m}$ deep) to the surface with a hand-towed plankton net ( $30 \mathrm{~cm}$ mouth diameter, $0.33 \mu \mathrm{m}$ mesh). All samples were dried at $60^{\circ} \mathrm{C}$ and ground into a powder that was analyzed for ${ }^{15} \mathrm{~N} /{ }^{14} \mathrm{~N}$ with a Finnegan MAT. Delta $E$ mass spectrometer after Minagawa \& Wada (1984). Results are expressed in per mil deviations from atmospheric nitrogen:

$$
\delta^{15} \mathrm{~N}=\left[\left(R_{\text {sample }} / R_{\text {atmospheric } \mathrm{N}}\right)-1\right] \times 1000,
$$

where $R={ }^{15} \mathrm{~N}:{ }^{14} \mathrm{~N}$.

\section{RESULTS}

\section{Gut contents}

Two types of particulate matter were identified from the gut of Conger myriaster leptocephali. One was a large particle of oval shape, 100 to $250 \mu \mathrm{m}$ diameter (Fig. 1A) and was found in $16.3 \%$ of guts examined (Table 1). The same particle was also observed in $2.3 \%$ of C. japonicus and $32.7 \%$ of Muraenosox cinereus. The mean number of particles contained in each gut was 4 (range: 1 to 31 ) and most of the particles were not disin-

Table 1. Gut contents of Conger myriaster, C. japonicus and Muraenosox cinereus leptocephali collected from the Seto Inland Sea (Japan)

\begin{tabular}{|lccccc|}
\hline Species & $\begin{array}{c}\text { Sampling } \\
\text { year }\end{array}$ & $\begin{array}{c}\text { No of specimens } \\
\text { examined }\end{array}$ & $\begin{array}{c}\text { Total length } \\
\text { range (mm) }\end{array}$ & $\begin{array}{c}\text { Gut content } \\
\text { Large particles } \\
\text { (fecal pellets) }\end{array}$ \\
\hline C. myriaster & 1989 (Mar-Apr) & 273 & $79.3-127.0$ & $217(79.5 \%)$ & $31(11.4 \%)$ \\
C. japonicus & 1990 (Mar-Apr) & 150 & $78.1-128.7$ & $112(74.7 \%)$ & $38(25.3 \%)$ \\
M. cinereus & 1989 (Mar) & 17 & $83.0-101.0$ & $16(94.1 \%)$ & $2(11.8 \%)$ \\
Total & 1990 (Mar-Apr) & 69 & $76.7-117.3$ & $69(100 \%)$ & $0(0 \%)$ \\
\hline
\end{tabular}




\section{A}
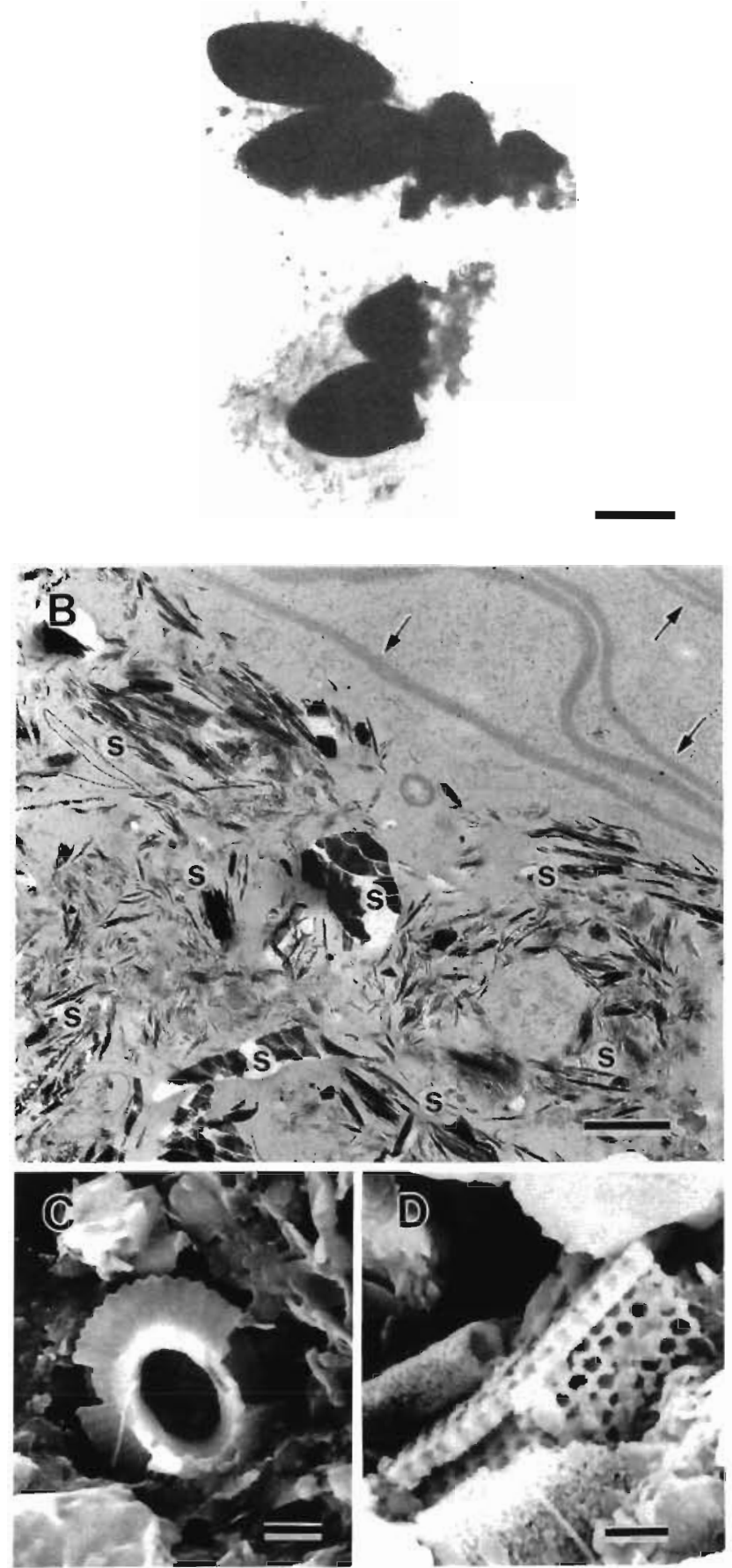

Fig. 1. Conger myriaster. Gut content (large particles) of a leptocephalus. (A) Overview of the particles. Two of them were broken in the treatment for extracting. Scale bar = $100 \mu \mathrm{m}$. (B) TEM micrograph of part of a particle. Arrows indicate envelopes of particle; S: presumed silica. Scale bar $=1 \mu \mathrm{m}$. (C) SEM micrograph of coccolith fragment from the particle. Scale bar $=1 \mu \mathrm{m}$. (D) SEM micrograph of diatom fragment from the particle. Scale bar $=1 \mu \mathrm{m}$. These photographs suggest the particle to be a fecal pellet of herbivorous zooplankton tegrating. They were covered by a mucous envelope (Fig. 1B) and included many fragments of coccoliths (Fig. 1C) and diatoms (Fig. 1D), indicating that they were fecal pellets of herbivorous zooplankton, i.e. Oikopleura spp. and copepods such as Acartia omorii, Calanus sinicus and Centropages abdominalis, which were abundant in plankton samples.

We commonly found another type of particle, which was small (less than $20 \mu \mathrm{m}$ in diameter) and amorphous (Fig. 2A). Under SEM it appeared to be an aggregation of smaller particles, less than $5 \mu \mathrm{m}$ in diameter, and mucous material (Fig. 2B). The aggregation was contained in large numbers in $77 \%$ of Conger myriaster, $99 \%$ of C. japonicus, and $90 \%$ of Muraenosox cinereus guts examined (Table 1). Under TEM the aggregation was found to be composed of numerous fine particles of less than $0.5 \mu \mathrm{m}$ diameter and vacuolelike amorphous materials which were less than $5 \mu \mathrm{m}$ in diameter and which included fine particles and membranous structures (Fig. 2C). The ultrastructural appearance of the particles comprising the aggregation was different from that of the fecal pellet contents (Fig. 1B). Their membranous structure suggests that they are particulate detritus originating from living organisms, although they might include some cytoplasmic inclusions from falling epithelial cells of the leptocephali themselves. Highly electron-dense material was sometimes found with the aggregation (Fig. 2C). On rare occasion we found electron-dense materials of presumed diatom fragments (Fig. 2D, E) and bacterialike bodies (Fig. 2F). The results of the gut content analysis suggest that detrital particles, including fecal pellets, are a major food item of leptocephali.

\section{Gut pigment contents}

The gut pigment content of Conger myriaster leptocephali was measured to assess grazing by leptocephali. Total pigment content was $0.94 \pm 0.27$ to $1.62 \pm 0.13$ (mean $\pm \mathrm{SD}$ ) $\mathrm{ng}$ ind ${ }^{-1}$ (Table 2). Based on Strathman's equation (1967), where the carbon/chl a ratio is 40 , these values correspond to only 100 to 200 diatom cells $(10 \mu \mathrm{m}$ diameter). Furthermore, the chl a/phaeopigment ratio was also quite low $(0.21 \pm 0.07$ to $0.71 \pm 0.36)$ (Table 2 ), suggesting that the pigment stayed in the gut for a long time or that it originated from detritus such as fecal pellets of herbivorous plankton.

\section{Ultrastructure of midgut mucosal epithelium}

The midgut epithelia of Conger myriaster leptocephali were composed of typical absorptive cells with developed microvilli and a small number of ciliated 
cells. Mucous cells were quite rare in the epithelium. The absorptive cells contained numerous vacuoles including fine particles throughout the cytoplasm (Fig. 3A). The density of vacuoles was quite high in the upper half of the cytoplasm, towards the lumen, and some apical vacuoles were found to be in contact with the plasma membrane of the luminal surface, suggesting that the vacuoles were involved in pinocytotic ingestion of macromolecules. In longitudinal sections, the vacuoles in the supranuclear area appeared as long flattened sacs arranged parallel to the long axis of the cell

\section{A}
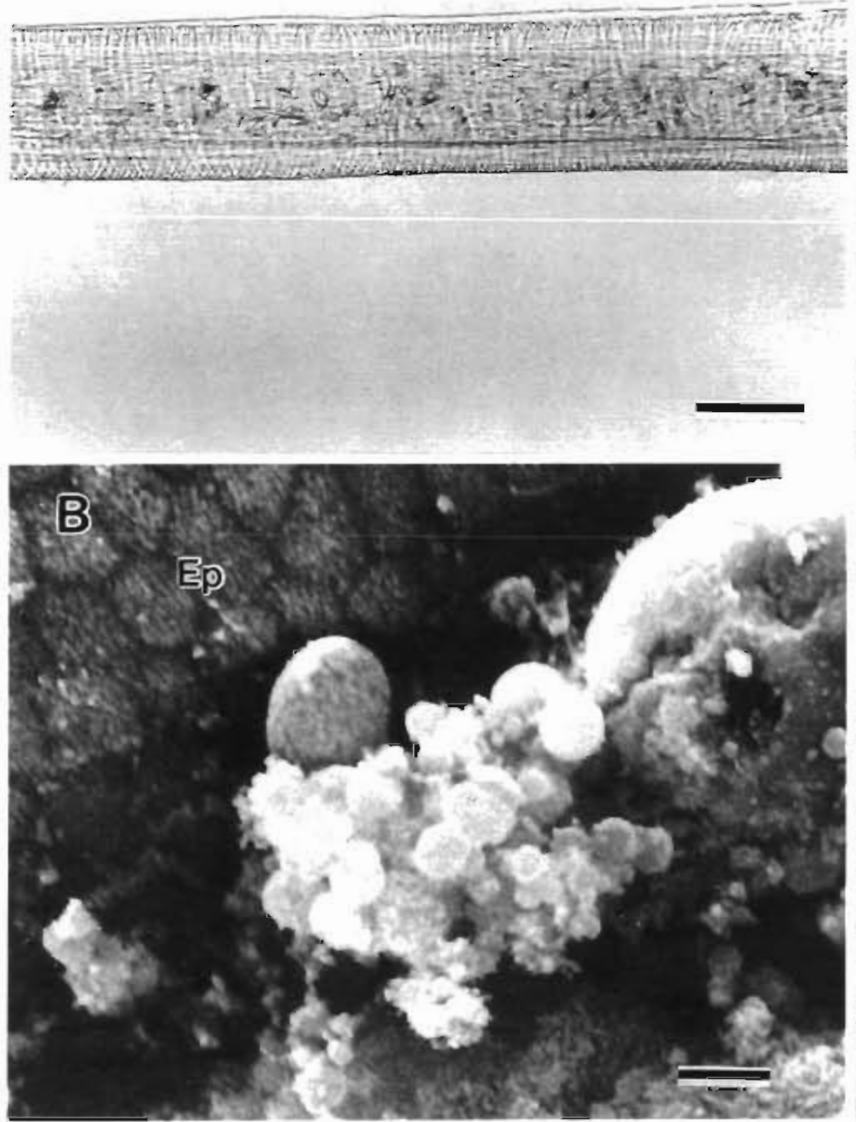

Fig. 2. Conger myriaster. Gut content (small particles) of a leptocephalus. (A) Overview of the particles in esophagus. The particles were found uniformly throughout the gut from the esophagous to the anal region. Scale bar $=200 \mu \mathrm{m}$. (B) SEM micrograph of a particle, showing it to be an aggregation of fine particles and amorphous material. Ep: gut epithelium. Scale bar $=5 \mu \mathrm{m}$. (C) TEM micrograph of the aggregation. Gl: gut lumen. Scale bar $=1 \mu \mathrm{m}$. (D \& E) TEM micrographs of fragments of presumed diatoms. Scale bars = $1 \mu \mathrm{m}$. (F) TEM micrograph of presumed bacteria-like body. Scale bar $=1 \mu \mathrm{m}$
(Fig. 3B). The end of the vacuoles were often pinched off and coalesced with each other to form large membrane-bound vacuoles with highly electron-dense particles (Fig. 3C)

The most striking feature in the cell was the highly developed membranous lamellar structure closely associated with large mitochondria occupying the basal half of the cytoplasm (Fig. 3D). Each membrane was found to be connected with basal plasma membranes, which indicated that the lamellar structure was an infolding of basal membrane. No relation was found
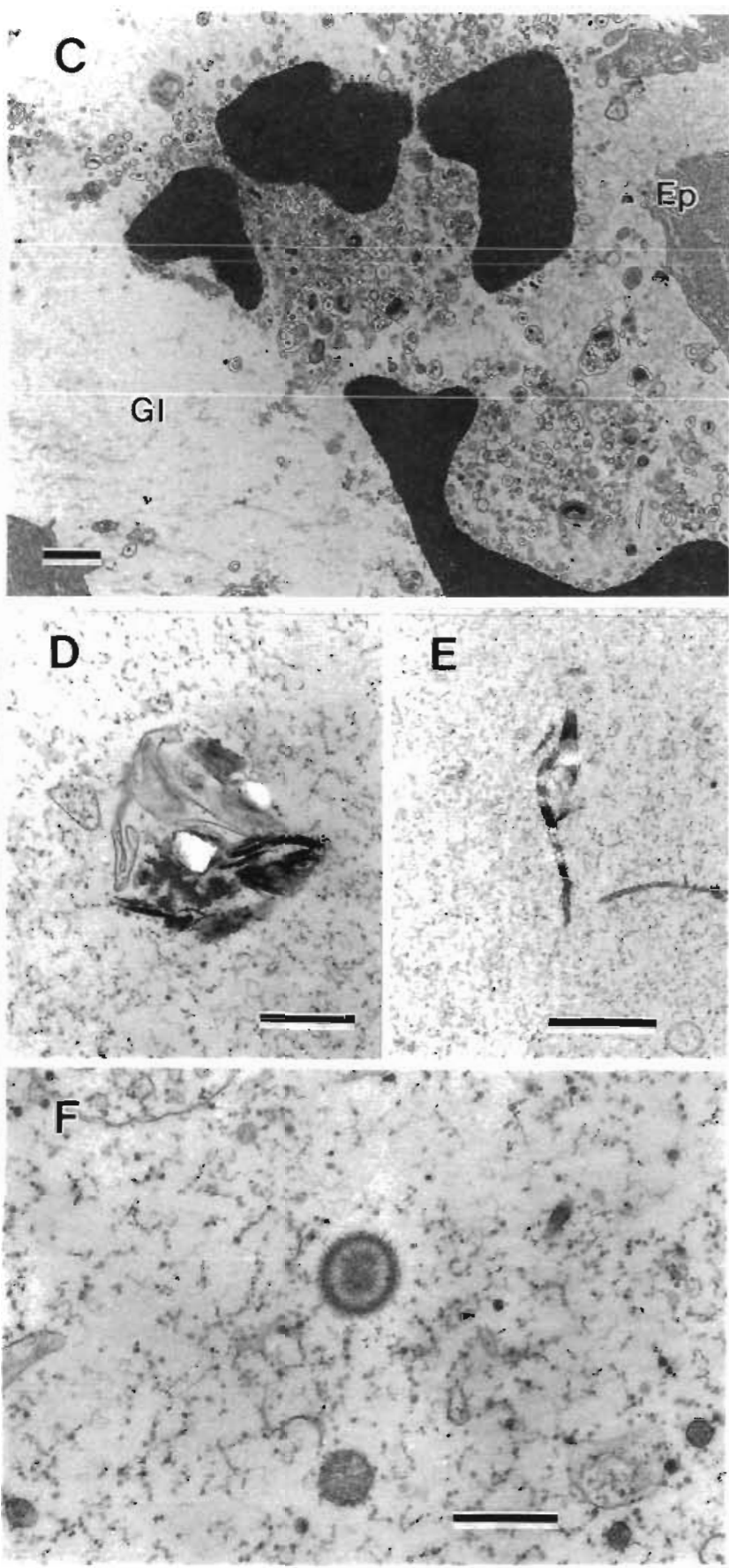
Table 2. Conger myriaster. Gut pigment contents and chl a/phaeopigment ratios in guts of leptocephall collected from the Seto Inland Sea (Japan) Values are means \pm SD

\begin{tabular}{|ccccc|}
\hline $\begin{array}{c}\text { No. of speci- } \\
\text { mens examined }\end{array}$ & $\begin{array}{c}\text { Sampling } \\
\text { month }\end{array}$ & $\begin{array}{c}\text { Total length } \\
\text { range }(\mathrm{mm})\end{array}$ & $\begin{array}{c}\text { Pigment content } \\
\text { (ng ind, }{ }^{1} \text { ) }\end{array}$ & Chla/phaeo \\
\hline 5 & Mar 1989 & $1030-1180$ & $162 \pm 013$ & $0.21 \pm 007$ \\
17 & Mar 1990 & $900-115.5$ & $0.94 \pm 027$ & $0.71 \pm 036$ \\
10 & Apr 1990 & $935-105.0$ & $1.11 \pm 029$ & $070 \pm 014$ \\
\hline
\end{tabular}
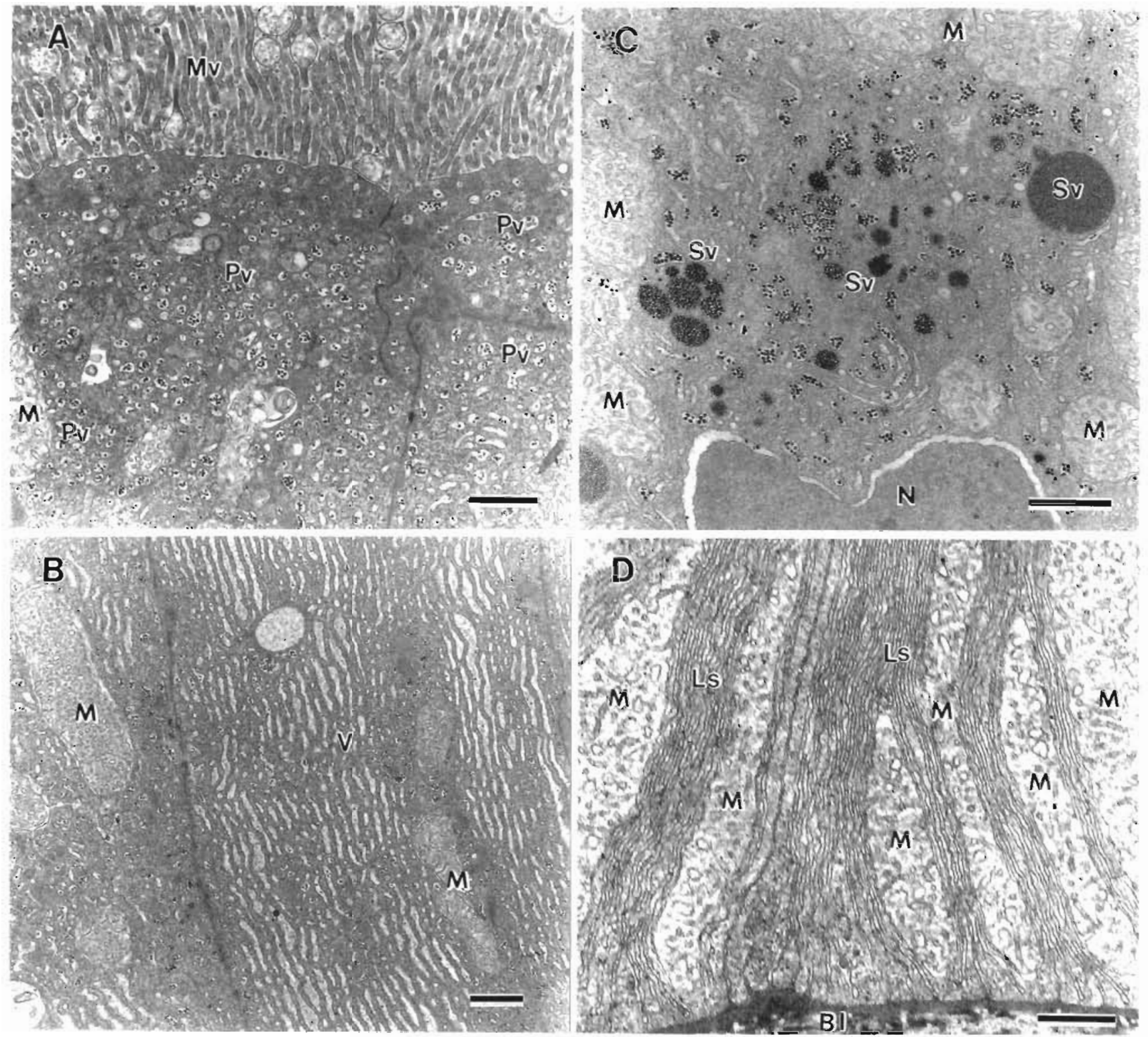

Fig. 3. Conger myriaster. TEM micrograph of midgut absorptive cell of a leptocephalus (A) Apical portion of the cytoplasm, numerous pinocytotic vesicles ( $\mathrm{Pv}$ ) including fine partıcles are present in the cytoplasm. Mv. microvillı; M mitochondria Scale bar $=1 \mu \mathrm{m}$. (B) Longitudinal section of supranuclear portion of the cytoplasm, long flattened vacuoles (V) are arranged parallel to the long axis of the cell. Scale bar $=1 \mu \mathrm{m}$ (C) Supranuclear portion of the cytoplasm. showing formation of supranuclear vacuoles (Sv). N: nucleus. Scale bar $=1 \mu \mathrm{m}$. (D) Basal portion of the cytoplasm; membranous lamellar structure (Ls) associated with large mitochondria (M) is highly developed. Bl basal lamina Scale bar $=0.5 \mu \mathrm{m}$ 
between the lamellar structure and the pinocytotic vacuoles distributed in the upper half of the cytoplasm.

\section{Stable nitrogen isotopic composition}

The nitrogen heavy isotopic composition in Conger myriaster leptocephali (11.1 to $11.2 \%$ ) was much lower than that of any of the other animals simultaneously sampled, and was slightly lower than that of the plankton sample containing copepods, Oikopleura and diatoms (Table 3). It was at the same level as POM comprising a mixture of detritus, bacteria, protozoa, phytoplankton, and microzooplankton. This fact shows that leptocephali are located at the lowest trophic level in the food web, and accordingly are unlikely to feed on zooplankton and other animals, which occupy higher trophic levels.

\section{DISCUSSION}

It is widely accepied that, in larvac and adult stomachless fishes, intact macromolecular protein is ingested and intracellularly digested in epithelial cells of the second (middle) segment of the gut, or hindgut (Yamamoto 1966, Iwai 1968, Gauthier \& Landis 1972, Noaillac-Depeyre \& Gas 1973, 1976. Stroband 1977, Stroband et al. 1979. Stroband \& Van Der Veen 1981, Watanabe 1981, 1982, 1984a, b, Deplano et al. 1991). Numerous pinocytotic vacuoles and supranuclear large vacuoles in the midgut absorptive cells of Conger myriaster leptocephali indicate the same mechanism of food ingestion and di- gestion to be occurring in leptocephali. Hulet (1978) suggested that the gut of Ariosoma balearicum leptocephali is not involved in nutrient absorption since it is poorly differentiated and the lumen is often occluded. In contrast, our present observations obviously demonstrate that the gut of $C$. myriaster is the active site of nutrient absorption.

The cytological features of the developed lamellar membranous structure in the basal half of the midgut epithelial cell are similar to the infoldings of lateral and basal plasma membrane which have been reported in the digestive system of various fishes and are thought to be involved in osmotic water and ion transport (Ozaki 1965, Yamamoto 1966, Iwai 1968, Noaillac-Depeyre \& Gas 1976, Stroband \& Debets 1978). Furthermore, in Muraenosox cinereus pre-leptocephali whose gut epithelial cells possessed the same cytological features as Conger myriaster $\mathrm{Na}^{+}-\mathrm{K}^{+}$ATPase activity has been demonstrated on both the lamellar membrane and the basal plasma membrane of midgut epithelial cells (Otake unpubl. data), which indicates the active $\mathrm{Na}^{+}$dependent solute transport in the cell. The highly developed lamellar structure in the midgut epithelial cell of $C$. myriaster leptocephali suggests that they actively absorb seawater. It is known that leptocephali have a high water content and that their ionic composition is in equilibrium with that of seawater, indicating their physiological immaturity with regard to osmoregulation (Hulet et al. 1972, Pfeiler 1986). Pfeiler (1986) reported that bonefish leptocephali contained high levels of essential amino acids, which they were presumably unable to synthesize by themselves, in spite of the absence of an obvious nutrient supply. And Hulet (1978) and Pfeiler (1986) suggested that leptocephali ob-

Table 3. Nitrogen isotopic composition of Conger myriaster leptocephali, particulate organic matter, invertebrates and fishes collected in the Seto Inland Sea (Japan). Values are means \pm SD for individuals analyzed

\begin{tabular}{|c|c|c|c|c|}
\hline \multirow[t]{2}{*}{ Samples } & \multicolumn{2}{|c|}{ April 1989} & \multicolumn{2}{|c|}{ April 1990} \\
\hline & $\begin{array}{c}\text { No. of } \\
\text { specimens }\end{array}$ & $\delta^{15} \mathrm{~N}$ & $\begin{array}{c}\text { No. of } \\
\text { specimens }\end{array}$ & $\delta^{15} \mathrm{~N}$ \\
\hline POM & 1 & 11.6 & $3^{d}$ & $13.3 \pm 0.24$ \\
\hline \multicolumn{5}{|l|}{ Invertebrates: } \\
\hline Plankton sample (zoo-, phytoplankton) & 1 & 11.9 & & \\
\hline Jellyfish & 2 & $17.5 \pm 2.4$ & & \\
\hline Squid (Loligo sp.) & 1 & 17.6 & 1 & 17.5 \\
\hline \multicolumn{5}{|l|}{ Fishes: } \\
\hline Ammodytes personatus & 2 & $17.8 \pm 1.8$ & 2 & $15.2 \pm 0.1$ \\
\hline A. personatus (larva) & & & $1^{b}$ & 15.2 \\
\hline Clupanodon punctatus & & & 1 & 17.1 \\
\hline Apogon lineatus & & & 1 & 18.0 \\
\hline Conger myriaster (leptocephalus) & 3 & $11.1 \pm 0.9$ & 3 & $11.2 \pm 1.4$ \\
\hline
\end{tabular}


tain nutrition from DOM, which reminds us of Pütter's theory (1909). Active seawater absorption in the gut epithelium of C. myriaster leptocephali seems to be involved in their nutrition rather than osmoregulation.

Recently, sub-micrometre particles, classified as DOM, were found to be present at high densities in the ocean (Koike et al. 1990, Toggweiler 1990, Longhurst et al. 1992) and have been proposed to be an important food source of oikopleurid tunicates (Flood et al. 1992). They are suggested to be of bacterial origin, and coagulate to form amorphous aggregates in seawater when they are observed with TEM (Koike et al. 1990). We found numerous fine particles of less than $0.5 \mu \mathrm{m}$ diameter with high electron density from both the gut lumen and the pinocytotic vesicles in the gut epithelial cells of Conger myriaster. Although we lack precise knowledge about the nature of the fine particles and evidence that they correspond to the sub-micrometre particles, it would be logical to suspect that the submicrometre particles are swallowed with seawater and absorbed by the gut epithelial cells of leptocephali.

The detrital particles including fecal pellets, collectively called 'particulate organic matter' or sometimes 'marine snow', are known to be sites of a dense community of phytoplankton, bacteria, and protozoa, and are rich in nutrients (Silver et al. 1978, Shanks \& Trent 1979, Caron et al. 1986). Accordingly, detrital particles have been suggested as a potential food for marine organisms (Alldredge 1972, 1976, Geber \& Marshall 1974, 1982, Shanks \& Trent 1980, Silver \& Alldredge 1981, Gottfried \& Roman 1983). Our gut content analysis showed that the detrital particles of biological origin are a major food item for eel leptocephali.

The gut pigment levels equivalent to between 100 and 200 diatom cells, seem too low for phytoplankton to be a major food of leptocephali of $100 \mathrm{~mm}$ total length, in which gut evacuation time is not so fast. In leptocephali, including Conger myriaster, the gut lumen becomes quite narrow due to proliferation of mucosal epithelium, and there is no muscle layer present around the epithelium (Hulet 1978, Otake unpubl. data), suggesting that the food evacuation is rather slow. Therefore, the low level of gut pigment implies that phytoplankton is less important as a food source of leptocephali. In addition, the low level of phytoplankton in the gut is evidence that the detrital particles are not incidentally ingested when leptocephali swallow seawater. Since the eyes and olfactory organ of leptocephali are well developed (Pfeiler 1989), they would ingested the detrital particles selectively using those sensory systems.

The leptocephali examined in the present study were all collected during daylight hours. We do not know whether leptocephali feed during the daytime or nighttime. However, amorphous particles similar to those found in the present study were observed as a major food item in guts of several species of pelagic leptocephali collected during the nighttime (Otake \& Mochioka 1993). Those facts indicate that leptocephali possibly feed on detrital particles both day and night.

The nitrogen stable isotopic composition of leptocephali was about the same as that of POM. The nitrogen heavy isotope is known to be enriched by 3 to $4 \%$ per trophic level (DeNiro \& Epstein 1981, Schoeninger \& DeNiro 1984, Minagawa \& Wada 1984, Wada et al. 1987, Fry 1988). Therefore, if leptocephali feed on POM as we suggest, they would be expected to have a slightly higher heavy isotopic level than that of POM. The isotopic composition of leptocephali indicates that their food includes matter with a lower isotopic level than that of POM, i.e., DOM present in seawater and lower trophic components of POM which contains substances originating from various trophic levels. The results provide evidence that DOM and POM are food sources for eel leptocephali.

Acknowledgements. We thank E. D. Houde, K. Tsukamoto and $\mathrm{M}$. Okiyama for critically reading the manuscript, $\mathrm{S}$. Nishida for helpful discussion, A. Tsuda for help in measuring gut pigment content, and K. Uozumi and N. Inoue for assistance in collecting specimens and studying gut content. This work was supported in part by Grant-in-Aid No. 63760144 from the Ministry of Education, Science and Culture, Japan.

\section{LITERATURE CITED}

Alldredge, A. L. (1972). Abandoned larvacean houses: a unique food source in the pelagic environment. Science 177: $885-887$

Alldredge, A. L. (1976). Discarded appendicularian houses as sources of food, surface habitats, and particulate organic matter in planktonic environments. Limnol. Oceanogr. 21: $14-23$

Caron, D. A., Davis, P. G., Madin, L. P., Sieburth, J. McN. (1986). Enrichment of microbial populations in macroaggregates (marine snow) from surface waters of the North Atlantic. J. mar. Res. 44:543-565

Castle, P. H. J. (1963). Anguillid leptocephali in the southwest Pacific. Zool. Publ. Victoria Univ. Wellington 33: 1-14

DeNiro, M. J., Epstein, S. (1981). Influence of diet on the distribution of nitrogen isotopes in animals. Geochim. cosmochim. Acta 45: 341-351

Deplano, M., Connes, R., Diaz, J. P., Barnabe, G. (1991). Variation in the absorption of macromolecular proteins in Larvae of the sea bass Dicentrarchus labrax during transition to the exotrophic phase. Mar. Biol. 110: 29-36

Flood, P. R., Deibel, D., Morris, C. C. (1992). Filtration of colloidal melanin from sea water by planktonic tunicates. Nature 355: 630-632

Fry, B. (1988). Food web structure on Georges bank from stable $C, N$, and $S$ isotopic compositions. Limnol. Oceanogr. 33: 1182-1190

Gauthier, G. F., Landis, S. C. (1972). The relationship of ultrastructure and cytochemical features to absorptive activity in the goldfish intestine. Anat. Rec. 172: 675-702 
Geber, R. P., Marshall, N. (1974). Ingestion of detritus by the lagoon pelagic community at Eniwetok Atoll. Limnol. Oceanogr. 19: 815-824

Geber, R. P., Marshall, N. (1982). Characterization of the suspended particulate organic matter and feeding by the lagoon zooplankton at Eniwetok Atoll. Bull. mar. Sci. 32: $290-300$

Gottfried, M., Roman, M. R. (1983). Ingestion and incorporation of coral-mucus detritus by reef zooplankton. Mar Biol. 72: 211-218

Hulet, W. H. (1978). Structure and functional development of the eel leptocephalus Ariosoma balearicum (de la Roche, 1809). Phil. Trans. R. Soc. Lond. (Ser. B.) 282: 107-138

Hulet, W. H., Fisher, J., Rietberg, B. J. (1972). Electrolyte composition of Anguilliform leptocephali from the straits of Florida. Bull. mar. Sci. 22: 432-448

Iwai, $T$ (1968). Fine structure and absorption patterns of intestinal epithelial cells in rainbow trout alevins. Z. Zellforsch $91: 366-379$

Jespersen, P. (1942). Indo-Pacific leptocephalids of genus Anguilla: systematic and biological studies. Dana Rep. 22 $1-128$

Koike, I., Hara, S., Terauchi, K., Kogure, K. (1990). Role of suumicrometre particles in the ocean. Nature 345: 242-244

Longhurst, A. R., Koike, I., Li, W. K. W., Rodgiguez, J., Dickie P., Kepay, P., Partensky, F., Bautista, B., Ruiz, J., Wells, M., Bird, D. (1992). Sub-micron particles in northwest Atlantic shelf water. Deep Sea Kes. 3y: 1-7

Minagawa, M. Wada, E. (1984). Stepwise enrichment of ${ }^{15} \mathrm{~N}$ along food chains. Further evidence and the relation between ${ }^{15} \mathrm{~N}$ and animal age. Geochim. cosmochim. Acta 48: $1135-1140$

Moser, H. G. (1981). Morphological and functional aspects of marine fish larvae. In: Lasker, R. (ed.) Marine fish larvae morphology, ecology, and relation to fisheries. Washington Sea Grant Program, Seattle, p. 90-13

Noaillac-Depeyre, J., Gas, N. (1973). Absorption of protein macromolecules by the enterocytes of the carp (Cyprinus carpio L.). Z. Zellforsch. 146: 525-541

Noaillac-Depeyre, J., Gas, N. (1976). Electron microscopic study on gut epithelium of the tench (Tinca tinca L.) with respect to its absorptive function. Tissue Cell 8: 511-530

Otake, T., Mochioka, N. (1993). Possible food sources of Japanese eel leptocephalus, Anguilla japonica. In Tsukamoto, K. (ed.) Preliminary report of the Hakuhomaru Cruise KH-91-4. Ocean Research Institute, Univ. of Tokyo (in press)

Ozaki, N. (1965). Some observations on the fine structure of the intestmal epithelium in some marine teleosts. Arch. Histol. Jap. 26: 23--38 (in Japanese)

Pfeiler, E. (1986). Towards an explanation of the developmental strategy in leptocephalous larvae of marine teleost fishes. Envir. Biol. Fish. 15: 3-13

Pfeiler, E. (1989). Sensory systems and behavior of premetamorphic and metamorphic leptocephalous larvae. Brain Behav. Evol. 34: 25-34

Pütter, A (1909). Die Ernährung der Copepoden. Arch. Hydrobiol 15: 70-117

Schoeninger, M. J., DeNiro, M. J. (1984). Nitrogen and carbon

This article was submitted to the editor isotopic composition of bone collagen from marine and terrestrial animals. Geochim. cosmochim. Acta 48: 625-639

Shanks, A. L., Trent, J D. (1979). Marine snow: microscale nutrient patches. Limnol. Oceanogr. 24: 850-854

Shanks, A. L., Trent, J. D. (1980). Marine snow: sinking rates and potential role in vertical flux. Deep Sea Res. 27A: $137-143$

Silver, M. W., Alldredge, A. L. (1981). Bathypelagic marine snow: deep-sea algal and detrital community. J. mar. Res. 39: $501-530$

Silver, M. W., Shanks, A. L., Trent, J. D. (1978). Marine snow: microplankton habitat and source of small-scale patchiness in pelagic populations. Science 201:371-37

Strathman, R. R. (1967). Estimating the organic carbon content of phytoplankton from cell volume or plasma volume. Limnol. Oceanogr. 12: 411-417

Strickland, J. D. H., Parsons, T. R. (1972). A practical handbook of seawater analysis, 2nd edn. Bull. Fish. Res. Bd Can. 167: 1-310

Stroband, H. W. J (1977). Growth and diet dependent structural adaptations of the digestive tract in juvenile grasscarp (Ctenopharyngodon idella, Val.). J. Fish Biol. 11: $167-174$

Stroband, H. W. J., Debets, F. M. H. (1978). The ultrastruclure and renewal of the intestinal epithelium of the juvenile grasscarp, Ctenopharyngodon idella (Val.). Cell Tissue Res. 187: 181-200

Stroband, H. W. J., Meer, H. v d.. Timmermans, L. P. M. (1979). Regional functional differentiation in the gut of the grasscarp, Ctenopharyngodon idella (Val.). Histochemistry 64: $235-249$

Stroband, H. W. J., Van der Veen, F. H. (1981). Localization of protein absorption during transport of food in the intestine of the grasscarp, Ctenopharyngodon idella (Val.). J. exp. Zool. 218: 149-156

Toggweiler, J. R. (1990). Diving into the organic soup. Nature 345: 203-204

Wada, E., Terazaki, M., Kabata, Y., Nemoto, T. (1987). ${ }^{15 N}$ and ${ }^{13} \mathrm{C}$ abundances in the Antarctic Ocean with emphasis on the biogeochemical structure of the food web. Deep Sea Res. 34: 829-841

Watanabe, $Y$ (1981). Ingestion of horseradish peroxidase by the intestinal cells in larvae or juveniles of some teleosts. Bull. Jap. Soc. Scient. Fish. 47: 1299-1307

Watanabe, Y (1982). Intracellular digestion of horseradish peroxidase by the intestine cells of teleost larvae and juveniles. Bull. Jap. Soc. Scient. Fish. 48: 37-42

Watanabe, Y (1984a). An ultrastructural study of intracellular digestion of horseradish peroxidase by the rectal epithelium cells in larvae of a freshwater cottid fish Cottus nozawae. Bull. Jap. Soc. Scient. Fish. 50: 409-41.6

Watanabe, Y (1984b). Morphological and functional changes in rectal epithelium cells of pond smelt during postembryonic development. Bull. Jap. Soc. Scient. Fish. 50 805-814

Yamamoto, T (1966). An electron microscope study of the columnar epithelial cell in the intestine of fresh water teleosts: goldfish (Carassius auratus) and rainbow trout (Salmo inideus). Z. Zellforsch. 72: 66-87

Manuscript first received: September 11,1991

Revised version accepted: November 24, 1992 